\title{
Peningkatan Nilai Ekonomi PDRB Kota Batam Melalui Pengembangan pada UMKM Cincai Cafe Batam
}

\author{
Jessy $^{* 1}$, Nadiva Surya Permata ${ }^{2}$, Rico Lim Gestu ${ }^{3}$, Rovina $^{4}$, Stella Theo ${ }^{5}$ \\ 1,2,3,4,5 Manajemen, Fakultas Ekonomi, Universitas Internasional Batam, Indonesia \\ Email: ${ }^{1} 2041191 . j e s s y @$ uib.edu, ${ }^{2} 2041242 . n a d i v a @ u i b . e d u,{ }^{3} 2041216 . r i c o @ u i b . e d u$, \\ 42041106.rovina@uib.edu, 52041208.stella@uib.edu
}

\begin{abstract}
Abstrak
UMKM Cincai Cafe Batam merupakan salah satu bagian dari aktivitas usaha kecil yang berada di wilayah Kota Batam. Pengembangan kegiatan UMKM Cincai Cafe Batam diharapkan oleh pemerintah daerah Kota Batam mampu mempengaruhi nilai pertumbuhan ekonomi PDRB Kota Batam yang menurun akibat dampak pandemi COVID-19. Tujuan dari penyusunan artikel adalah untuk mengetahui upaya peningkatan nilai ekonomi PDRB di Kota Batam melalui pengembangan terhadap UMKM Cincai Cafe Batam selama masa pandemi ini. Metode penyusunan artikel yang diketahui adalah menggunakan pendekatan kualitatif dengan teknik pengumpulan data sekunder berupa observasi dan sumber penelitian terdahulu, serta teknik pengolahan data dengan analisis deskriptif. Hasil penyusunan artikel menunjukkan adanya pengembangan mitra mempengaruhi signifikan positif terhadap nilai ekonomi PDRB di Kota Batam. Kesimpulan dari artikel adalah bahwa nilai pertumbuhan ekonomi nasional dan daerah menjadi tanggung jawab milik bersama. Berdasarkan penjelasan yang telah dituliskan, maka dapat diberikan beberapa saran diantaranya bagi mitra yaitu untuk selalu mengembangkan seluruh sistem manajemen operasionalnya meskipun telah berakhir menghadapi masa pandemi.
\end{abstract}

Kata kunci: PDRB, Pengembangan, UMKM Cincai Cafe

\begin{abstract}
Cincai Cafe Batam is a small business activities in the Batam City. The development of Cincai Cafe Batam's activities is expected by the Batam Regional Government to be able to influence the value of Batam City's PDRB economic growth which has decreased due to the impact of the COVID-19 pandemic. The purpose of compiling the article is to find out efforts to increase the value of PDRB in Batam City through the development of Cincai Cafe Batam during the pandemic. The method of articles is using a qualitative approach with secondary data collection techniques in the observations and sources of previous research, as well as data processing techniques with descriptive analysis. The results of the article indicate that the development of Cincai Cafe Batam has a positive impact on the value of the PDRB of Batam City. The conclusion of the article is that the value of national and regional economic growth is a shared responsibility. This is evidenced by the cafe development activity which increased this pandemic which is useful for obtaining business income, as encouraging growth. Based on the explanation, some suggestions can be given, including this cafe to always develop their entire operational management system.
\end{abstract}

Keywords: Cincai Cafe, Development, PDRB

\section{PENDAHULUAN}

Perekonomian suatu negara menjadi aspek penting sebagai bukti bahwa adanya stabilitas kesejahteraan dan pemerataan hasil pendapatan masyarakat. Indonesia merupakan salah satu negara yang juga mengupayakan pertumbuhan ekonomi negara agar terus dapat mengembangkan nilai ekonomi negara dan pendapatan masyarakat seiring berjalannya waktu hingga selalu mencapai tujuan yang diinginkan. Namun, sejak adanya pandemi COVID-19 yang dialami Indonesia pada awal Maret 2020 hingga saat ini diketahui bahwa Indonesia mengalami penurunan nilai ekonomi yang cukup anjlok (Dama et al., 2016). Hal ini tercatat pada laju pertumbuhan ekonomi nasional tahun 2020 mengalami pertumbuhan bersifat negatif sehingga nilai ekonomi pada kuartal I 2020 tumbuh 2,97\% 
year of year, sedangkan pada kuartal II 2020 tumbuh mencapai 5,32\% year of year (Romhadhoni et al., 2019). Adapun nilai pertumbuhan ekonomi Indonesia dikatakan cukup mengalami kesulitan untuk memeratakan kebutuhan dan pendapatan masyarakat akibat pengaruh masa pandemi (Kinanda, 2021).

Selama masa pandemi COVID-19 diketahui bahwa pemerintah juga menerapkan kebijakan adanya pembatasan aktivitas masyarakat maupun pelaku usaha untuk menetapkan segala aturan yang diberikan pemerintah seperti mematahui protokol kesehatan, membatasi waktu operasional kegiatan, serta mengurangi aktifitas di luar rumah yang digantikan dengan melakukan seluruh kegiatan seharihari melalui rumah secara online terutama untuk bekerja dan belajar (Ristyawati, 2020). Adapun hal ini tentu berdampak bagi hasil pendapatan masyarakat yang terhambat untuk melaksanakan kegiatan bekerja, sehingga nilai pertumbuhan ekonomi daerah juga sebagai faktor nilai ekonomi nasional yang rendah (Muhtadi et al., 2021).

Nilai ekonomi suatu daerah dikenal sebagai Produk Domestik Regional Bruto (PDRB) yang dimiliki setiap wilayah di Indonesia, salah satunya wilayah Kota Batam. PDRB di Kota Batam juga mengalami hal yang serupa dengan penurunan ekonomi yang hampir anjlok sehingga banyak sekali perputaran pendapatan yang terhambat (Romhadhoni et al., 2019). Pemerintah Daerah Kota Batam melihat fenomena ini tentu mengupayakan berbagai macam cara agar mengembalikan stabilitas ekonomi daerah (Hamzah et al., 2021). Salah satu upaya yang dilakukan yaitu mengembangkan kegiatan Usaha Mikro, Kecil, dan Menengah (UMKM) dengan tujuan mendorong nilai pertumbuhan PDRB Kota Batam (Lamazi, 2020). Setiap produk dari suatu UMKM, baik itu berupa barang ataupun jasa memiliki mereknya tersendiri yang membedakan dengan produk sejenis lainnya yang ada pada pasaran(Indrawati \& Setiawan, 2020).

UMKM Cincai Cafe Batam adalah salah satu dari bagian kegiatan pelaku usaha kecil yang berada di Kota Batam. Cincai Cafe Bata mini berfokus pada usaha yang menawarkan produk berupa olahan makanan dan minuman dengan target pasar kalangan millennial Kota Batam. Usaha ini didirikan sejak 20 Maret 2020 yang berlokasi di Jl. Bunga Raya NO.1 atau sebelah BCS Mall, Kota Batam. Seluruh menu yang ditawarkan usaha ini memiliki rentang harga yang cukup ekonomis dengan rasa berkualitas tinggi. Omset pendapatan UMKM Cincai Café Batam diperkirakan setiap bulan mencapai 30 juta rupiah, dengan perkiraan satu tahun kegiatan Cincai Cafe mampu memperoleh hingga 360 juta rupiah.

Melihat keadaan pandemi COVID-19 diketahui UMKM Cincai Cafe Batam juga mengalami penurunan hasil omset akibat berkurangnya jumlah pelanggan. Sehingga, pelaku usaha Cincai Cafe Batam dan Pemerintah Daerah Kota Batam saling bekerja sama untuk meningkatkan nilai ekonomi yang menguntungkan bagi pelaku usaha dan nilai pertumbuhan PDRB Kota Batam.

Oleh karena itu, pada penyusunan artikel ini akan dilakukan pembahasan terkait upaya dan strategi dalam meningkatkan pendapatan yang akan membawakan dampak signifikan terhadap keberlangsungan dari operasional UMKM Cincai Cafe. Hal ini dilakukan dalam rangka untuk mendorong dan mempengaruhi nilai pertumbuhan ekonomi PDRB wilayah Kota Batam.

\section{METODE PENELITIAN}

Dalam menyusun penelitian ini menggunakan penerapan metode pendekatan kualitatif. Pendekatan metode kualitatif adalah upaya mengamati objek tertentu yang sesuai dengan postpositivisme dengan melihat semua instrumen utama yang diusahakan menggunakan teknik pengumpulan dan triangulasi tertentu (Sugiyono, 2017).

Adapun penelitian juga memanfaatkan teknik pengumpulan datanya menggunakan data sekunder yaitu sumber data yang dikumpulkan secara tidak langsung, tetapi dalam bentuk tertulis yang berasal dari pengolahan data dari hasil sebelumnya dalam jurnal penelitian sebelumnya, buku, berita, dan fenomena yang terjadi dari lingkungan sekitar dalam penelitian. Sedangkan, teknik analisis data menggunakan deskriptif kualitatif yang menggambarkan dan merangkum semua fenomena dan mengumpulkan data yang telah diperoleh dengan mengamati dari sudut pandang hasil penelitian yang telah dilakukan.

Dalam melakukan penelitian ini, peneliti memperoleh data dengan cara melakukan wawancara dan observasi terhadap UMKM Cincai Cafe. Salah satu metode penelitian yang digunakan yaitu berupa metode analisis naratif, yang berfokus pada bagaimana suatu ide atau cerita dikomunikasikan 
kepada seluruh bagian terkait. Peneliti menggunakan metode penelitian ini untuk membentuk suatu interpretasi tentang proses operasional dan penilaian pelanggan agar dapat membentuk suatu konsep strategi pemasaran yang sesuai dengan mitra serta mengimplementasikan rencana bersama pihak yang terlibat untuk mengembangkan mitra kedepannya

\section{HASIL DAN PEMBAHASAN}

UMKM Cincai Cafe Batam dalam menghadapi masalah selama pandemi COVID-19 karena mengalami penurunan hasil pendapatan tentu telah berupaya penyesuaian sistem operasional guna meningkatkan jumlah pelanggan, serta mendorong pertumbuhan nilai ekonomi PDRB Kota Batam. Kegiatan Cincai Cafe Batam sejak awal berdiri diketahui telah melakukan strategi pemasaran dengan beberapa cara diantaranya yaitu membuat banner dan brosur yang berisi produk-produk yang akan mereka jual, mengiklankan seluruh produk yang ditawarkan kepada target pelanggan khususnya masyarakat Kota Batam melalui media sosial seperti Facebook, Twitter, dan Instagram, serta pemanfaatan obrolan rekomendasi cafe dari mulut ke mulut. Perkembangan teknologi membantu usaha bisnis berkembang dalam praktik pemasarannya melalui strategi digital marketing dalam meningkatkan kepuasan pelanggan.

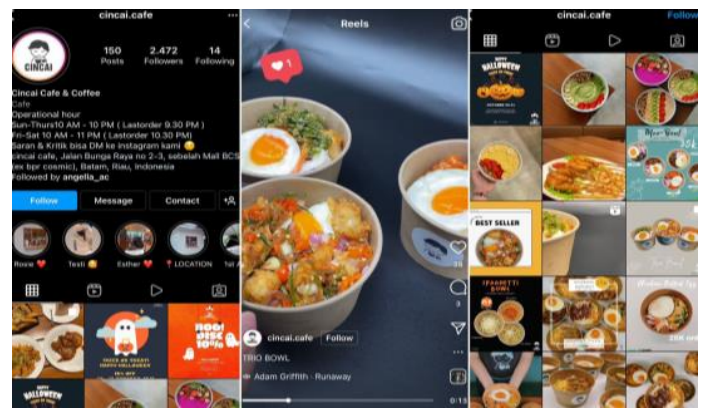

Gambar 1. Pemasaran UMKM Cincai Cafe melalui media sosial

Dalam mengembangkan mitra, maka diperlukan analisis mengenai lingkungan eksternal maupun internal dari suatu bisnis untuk menentukan strategi bisnis yang efektif dengan mempertimbangkan faktor-faktor yang berpengaruh. Dengan adanya analisis ini akan mempermudah pemilik usaha dalam melihat kelebihan dan kekurangan supaya adanya improvisasi pada proses bisnis. Dalam melakukan penelitian ini, metode analisis SWOT (Strength, Weakness, Opportunity, Threats) dipilih oleh peneliti sebagai cara yang sesuai untuk menilai mitra. Hal ini dilakukan dalam upaya untuk membentuk strategi yang sesuai dalam mengembangkan UMKM Cincai Cafe. Maka dari itu, hasil yang diperoleh dari dilakukannya analisa ini, yaitu:

Tabel 1. Analisa SWOT pada UMKM Cincai Cafe

\begin{tabular}{|c|c|}
\hline Analisa & Keterangan \\
\hline Strength & $\begin{array}{l}\text { Variasi menu yang ditawarkan beragam, sehingga memberi konsumen banyak } \\
\text { pilihan dan tempat usaha mitra dilengkapi dengan dekorasi yang estetik, } \\
\text { menarik serta suasana yang nyaman. }\end{array}$ \\
\hline Weakness & $\begin{array}{l}\text { Pemasaran di sosial media hanya dilakukan secara berkala saja, dan pesanan } \\
\text { online yang diterima masih belum begitu banyak sehingga tidak banyak ulasan } \\
\text { pada mitra di aplikasi GoFood. }\end{array}$ \\
\hline Opportunity & $\begin{array}{l}\text { Lokasi mitra yang strategis di tengah-tengah kota yang menjadikan UMKM } \\
\text { Cincai Cafe menjadi pilihan para anak muda sebagai tempat nongkrong dan } \\
\text { bersantai, serta diselenggarakan acara dan promo menarik di hari besar tertentu } \\
\text { misalnya pada hari natal, ulang tahun mitra, dan lain-lain. }\end{array}$ \\
\hline Threats & $\begin{array}{l}\text { Banyaknya cafe di Kota Batam yang menawarkan produk serupa dengan harga } \\
\text { yang lebih rendah, dan adanya dampak dari pandemi COVID-19 yang } \\
\text { menyebabkan menurunnya konsumen yang makan di tempat sehingga }\end{array}$ \\
\hline
\end{tabular}


terjadinya penurunan pada pendapatan UMKM Cincai Cafe.

Namun, UMKM Cincai Cafe Batam di tengah masa pandemi tentu tidak dapat bergantung pada cara pemasaran produk seperti yang telah dilakukan sebelumnya. Hal ini membuat sistem operasional pemasaran UMKM Cincai Cafe Batam mengalami perubahan dengan menyesuaikan keadaan lingkungan dan masyarakat selama pandemi, terutama untuk menjaga protokol kesehatan dan mengurangi interaksi secara langsung dengan pelanggan. Beberapa strategi dan upaya pemasaran yang diterapkan UMKM Cincai Cafe Batam diantaranya seperti membuat iklan melalui media sosial TikTok dengan konten berupa video unik dan menarik guna memperluas target pasar kalangan milenial Kota Batam. Pemilihan media sosial TikTok disebabkan banyaknya masyarakat yang menjadi pengguna TikTok selama masa pandemi, serta adanya istilah "Racun TikTok" dapat mempermudahkan kegiatan usaha Cincai Cafe Batam mencapai target pelanggan yang diinginkan. Hal ini juga dipengaruhi karena seluruh informasi yang disebarkan di media sosial TikTok tidak kalah cepat dengan platform media sosial lainnya. Media sosial merupakan salah satu cara digital marketing yang membawakan banyak pengaruh terhadap nama/reputasi dari sebuah mitra (Fauzi et al., 2021).

Selain itu, melihat adanya pembatasan kegiatan antara masyarakat membuat UMKM Cincai Cafe Batam mengembangkan usahanya dengan bekerja sama melalui Grab dan Gojek sebagai ojek online yang dapat mengantarkan pesanan produk makanan atau minuman yang diinginkan pelanggan. Kemudahan dari kerjasama dengan layanan ini membuat pelanggan dan penjual merasa lebih aman untuk bertransaksi jual beli di tengah pandemi. Tidak hanya itu, pihak mitra juga memberikan penawaran menarik melalui layanan tersebut yakni dengan potongan harga menggunakan voucher tertentu yang telah ditentukan oleh pihak mitra, serta adanya gratis ongkos kirim bagi pelanggan yang telah memenuhi minimal pembelian produk mitra tertentu.

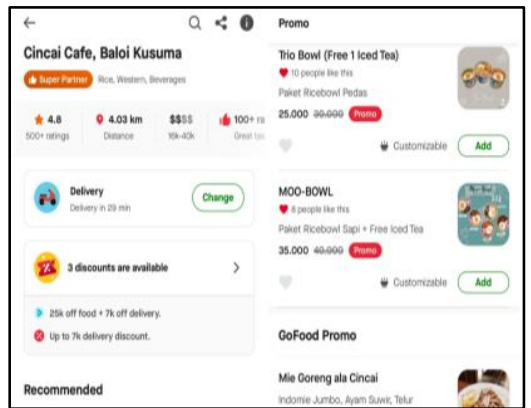

Gambar 2. UMKM Cincai Cafe bekerjasama dengan GoFood Batam

Adanya strategi pemasaran yang dikembangan Cincai Cafe Batam sebagai upaya peningkatan hasil pendapatan di tengah pandemi diketahui telah mampu mencapai target dari kegiatan usaha, seperti meningkatkan jumlah pelanggan dengan pembelian secara online meskipun hal tersebut dialami secara perlahan namun dapat memperluas target pelanggan dari seluruh wilayah Kota Batam, produk yang ditawarkan UMKM Cincai Cafe Batam telah banyak dikenal kalangan millennial, serta hasil pendapatan UMKM Cincai Cafe Batam juga mengalami peningkatan secara stabil. Secara signifikan, hasil pendapatan UMKM Cincai Cafe Batam tercatat mengalami kenaikan meskipun tidak seperti sebelum terkena dampak pandemi COVID-19. 


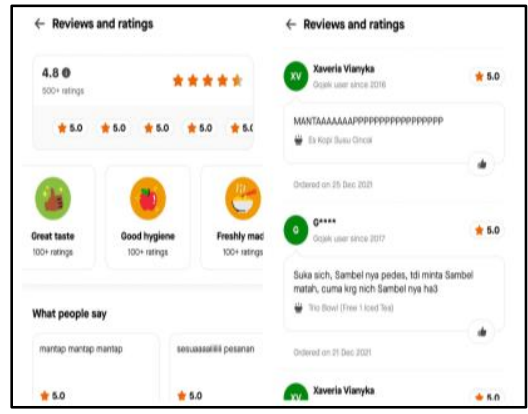

Gambar 3. Penilaian konsumen terhadap UMKM Cincai Cafe

Kemajuan yang dialami mitra tentu juga mempengaruhi peningkatan terhadap pertumbuhan nilai ekonomi PDRB Kota Batam yang secara signifikan telah didukung atas perkembangan kegiatan UMKM yang dialami Cincai Cafe Batam. Hal ini dikarenakan adanya perputaran transaksi ekonomi yang telah dilakukan oleh masyarakat Kota Batam. Selain itu, adanya keberhasilan pengembangan UMKM Cincai Cafe Batam tentu jika ditambahkan dengan secara menyeluruh mengembangkan kegiatan pelaku UMKM lainnya maka dapat dipastikan bahwa nilai pertumbuhan ekonomi PDRB wilayah Kota Batam akan semakin meningkat secara stabil. Apabila nilai PDRB Kota Batam mengalami pertumbuhan dengan baik, maka hal tersebut juga mempengaruhi pertumbuhan dari pendapatan ekonomi nasional suatu negara.

\section{KESIMPULAN}

Berdasarkan penjelasan yang telah dijabarkan, dapat disimpulkan bahwa nilai pertumbuhan ekonomi nasional dan daerah menjadi tanggung jawab milik bersama. Hal ini dibuktikan dari adanya kegiatan pengembangan UMKM Cincai Cafe Batam yang melakukan peningkatan hasil pendapatan di tengah masa pandemi guna bertujuan memperoleh pemasukan usaha yang stabil, serta mendorong pertumbuhan nilai ekonomi PDRB di Kota Batam. Berbagai macam upaya dan strategi pemasaran menjadi fokus utama mitra dalam mengupayakan keberhasilan usaha selama pandemi. Hal ini menunjukkan keberhasilan karena Cincai Cafe Batam mampu mencapai target pelanggan baru, meningkatkan hasil penjualan produk, serta mendukung pergerakan nilai ekonomi PDRB Kota Batam.

\section{DAFTAR PUSTAKA}

Dama, H. Y., Lapian, A. L. C., Sumual, J. I., Pembangunan, J. E., Ekonomi, F., Sam, U., \& Manado, R. (2016). Pengaruh Produk Domestik Regional Bruto (Pdrb) Terhadap Tingkat Kemiskinan Di Dewi, R. K., Sari, D., \& Wahyuningsih, D. W. (2021). Economics and Development Analysis. Inspire Journal:Economics and Development Analysis |, 1, No. 1, 47-60.

Fauzi, R. U. A., Kadi, D. C. A., Ernanda, G. K. S., Triwidya, P., \& Adhelia, S. (2021). Keefektifan Peran Digital Marketing Melalui Media Sosial Dalam Proses Pemasaran Produk Galeri UMKM Ekawira, Kare Madiun. Indonesia Berdaya, 2(1), 21-30. https://doi.org/10.47679/ib.202176

Hamzah, H., Valeriani, D., \& Yusfany, A. (2021). Pengaruh Variabel Makro Ekonomi Terhadap Indeks Harga Saham LQ-45 Di Bursa Efek Indonesia. Sorot, 16(2), 85. https://doi.org/10.31258/sorot.16.2.85-98

Indrawati, S., \& Setiawan, B. (2020). Upaya Peningkatan Kesadaran Hukum Perlindungan Produk UMKM di Kabupaten Kebumen Melalui Pendaftaran Merek. Surya Abdimas, 4(2), 37-43. https://doi.org/10.37729/abdimas.v4i2.574

Muhtadi, R., Karimah, \& Kamali. (2021). Strategi Penanggulangan Pengangguran Melalui Peran Usaha Kecil Menengah (Ukm) Genting. 2(01), 107-131. https://ejournal.inzah.ac.id/index.php/arribhu/article/view/550

Kinanda, F. (2021). the Effect of Macroeconomic Variables on Indonesian Economic Growth 20152019. 2(2). 
Lamazi, L. (2020). Pengaruh UMKM terhadap Pertumbuhan Ekonomi di Sumatera Selatan. Juripol (Jurnal Institusi Politeknik Ganesha Medan), 3(1), 103-108. https://doi.org/10.33395/juripol.v3i1.10491

Regional, D., Pdrb, B., \& Kabupaten, D. I. (2017). 2) 131. 20(1), 131-139.

Rapitasari, D. (2019). Сучасні Тенденції Розвитку Digital Marketing В Україні. Бизнес Информ, $10(4(495)), 107-112$.

Ristyawati, A. (2020). Efektifitas Pembatasan Sosial Berskala Besar Dalam Masa Pandemi Corona Virus. Administrative Law \& Governance Journal, 3(2), 240-249.

Romhadhoni, P., Faizah, D. Z., \& Afifah, N. (2019). Pengaruh Produk Domestik Regional Bruto (PDRB) Daerah terhadap Pertumbuhan Ekonomi dan Tingkat Pengangguran Terbuka di Provinsi $\begin{array}{lllll}\text { DKI Jakarta. Jurnal Matematika Integratif, } & 113 .\end{array}$ https://doi.org/10.24198/jmi.v14.n2.19262.113-120

Sugiyono. (2017). Strategi Komunikasi Pemasaran Cleans Dengan Metode Benchmarking. Jurnal Manajemen Dan Start-Up Bisnis, Vol.3(No.4), 1-10. 